\title{
Carnosinase Deficiency: a New Variant with High Residual Activity
}

\author{
LYNN D. FLEISHER, ${ }^{(12)}$ DAVID K. RASSIN, KRYSTYNA WISNIEWSKI, AND HELEN R. SALWEN \\ Department of Human Development and Nutrition, and Department of Pathological Neurobiology, New York State \\ Institute for Basic Research in Mental Retardation, Staten Island New York, and Division of Medical Genetics and \\ Department of Pediatrics, Mount Sinai School of Medicine of the City University of New York, USA
}

Summary

Plasma carnosinase deficiency was discovered in a 12-yr-old male with profound mental retardation, severe athetoid spastic quadriparesis, optic atrophy, sensory peripheral neuropathy, and suprabulbar signs. Amino acid analysis revealed persistent carnosinuria but no detectable carnosinemia. After ingestion of L-carnosine $(100 \mathrm{mg} / \mathrm{kg})$, the patient had carnosine in his plasma and excreted $28 \%$ of the administered load as carnosine (an agematched control excreted $1.3 \%$ as carnosine). Urinary 1-methylhistidine was measurable in the patient and increased greatly during a high anserine diet. Plasma carnosinase activity in the patient was $0.28 \mu$ moles per ml plasma per $\mathrm{hr}$ (control mean, 2.00; range, 1.10-2.85), his parents had activity of 1.36 and 1.30, and 2 sibs had activities of 1.10 and 1.86. Carnosinase activity in liver from the patient was $43 \%$ of control liver. We have demonstrated that carnosinase activity is present in human nerve and that sural nerve from the patient had activity that was $46 \%$ of control nerve. Histopathologic examination of the patient's nerve showed axonal degeneration. Histidine levels in cise patient's liver and nerve were normal, and neither $\beta$-alanine nor carnosine was detectable. The unusually high residual carnosinase activity in plasma and tissues from this patient may explain his apparent ability to metabolize anserine and would suggest that this represents a new variant form of carnosinase deficiency.

\section{Speculation}

Carnosinuria due to plasma camosinase deficiency may be merely associated with the striking neurologic findings that have been reported rather than causally related.

Normal human plasma contains the enzyme carnosinase (EC 3.4.13.3), which hydrolyzes the dipeptide carnosine to $\beta$-alanine and histidine.

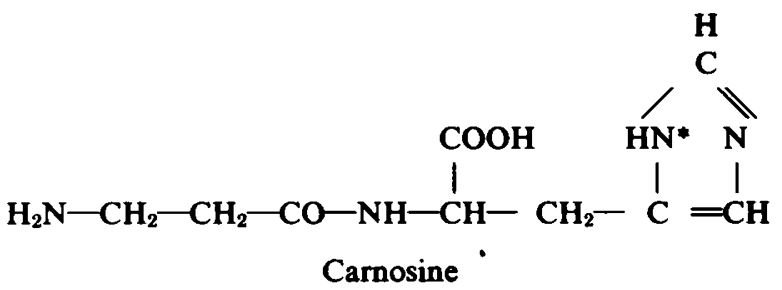

CARNOSINASE

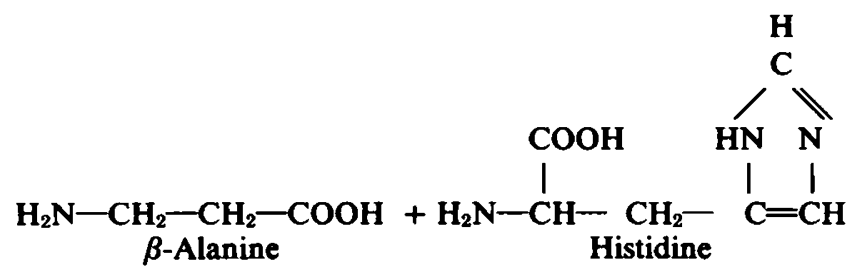

The same enzyme also hydrolyzes anserine, which is the $1^{*}$-methyl analog of carnosine to $\beta$-alanine and 1-methyl-histidine. Seven patients from four pedigrees have been reported with a biochemical abnormality consisting of persistent carnosinuria and an almost total deficiency of plasma carnosinase activity $(3,5,6,8$, 9). Carnosinemia has also been present in some cases. The carnosinuria persists in these patients even when there is no dietary source of carnosine.

Plasma carnosinase deficiency is difficult to establish with certainty during early childhood because the enzyme activity is age dependent (3). Enzymatic activity is low or absent in infancy and increases with variability during childhood to reach adult activity by 10 to 12 years. Two forms of tissue carnosinase are distinguish. able by starch block electrophoresis, and one of these forms was shown to be deficient in an affected child, accompanied by an almost complete absence of serum activity $(3,4)$.

The data thus far suggest an autosomal recessive pattern of inheritance. Most of the probands have been ascertained because of a profound deteriorative convulsive disorder. The neurologic symptoms, usually myoclonic seizures and psychomotor retardation, generally appear during the first year of life and are accompanied by nonspecific electroencephalographic abnormalities.

Table 1. Urinary amino acids ( $(\mu$ moles $/ 24 \mathrm{hr}$ )

\begin{tabular}{lccc}
\hline \multicolumn{1}{c}{ Subject } & Carnosine & Histidine & {$\left[1-\mathrm{CH}_{3}\right]$ Histidine } \\
\hline Patient & & & \\
Regular diet & 472 & 552 & 45 \\
No meat & 121 & 281 & 36 \\
Chicken diet & 435 & 417 & 1423 \\
Control & 46 & 1937 & 66 \\
\hline
\end{tabular}

Later infancy and childhood are characterized by spasticity and severe mental retardation. The clinical picture, however, is not entirely consistent, and two children have been reported to be carnosinuric but completely symptom free $(2,3)$. These observations suggest that carnosinase deficiency may not be causally related to the neurological findings.

\section{CLINICAL SUMMARY}

S. T. is a 12-year-old mentally retarded boy who has resided in an institution since 2 years of age. He was the product of a normal pregnancy and delivery. The family history is unremarkable, and there are 2 healthy sibs. His perinatal and postnatal development was uneventful, and he appeared normal until 4 to 5 months of age when he developed myoclonic seizures and began to regress. By 2 years of age, he was profoundly mentally retarded and had a spastic athetoid quadriparesis. By 3 to 4 years, he had experienced several grand mal seizures, and optic atrophy and suprabulbar signs were noted. The child's mental and motor age is 5 to 6 months. At 11 years of age, sensory peripheral neuropathy was noted. At that time, we also identified a large amount of the dipeptide carnosine in his urine. Neuropathological studies of the patient are reported in a separate publication (10). 
Table 2. Urinary amino acids after a carnosine load ( $\mu$ moles/hr)

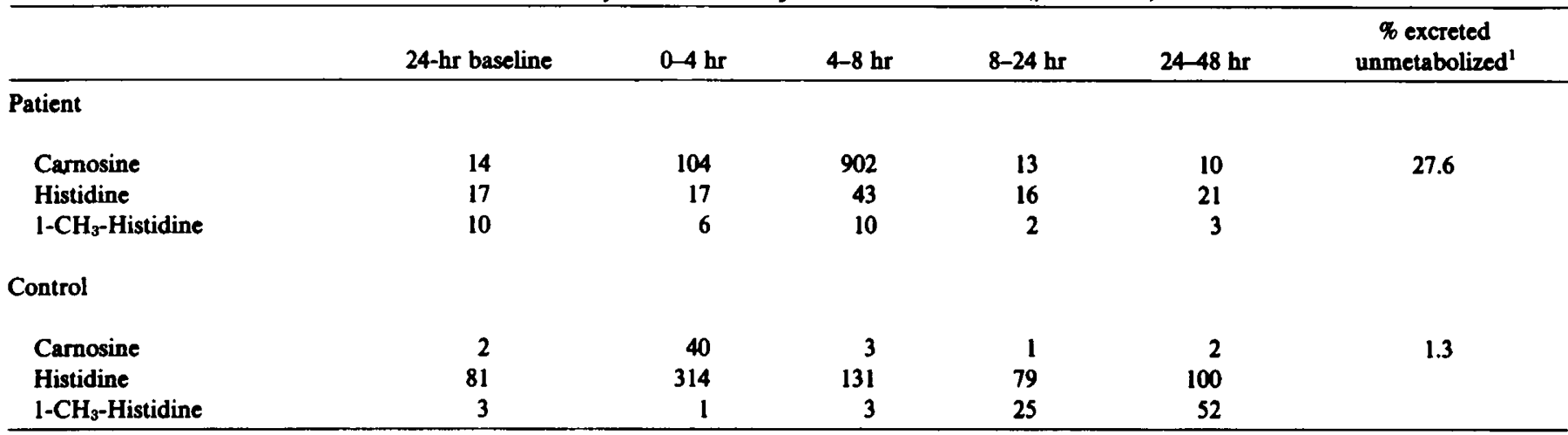

'The percentage of the carnosine load excreted unmetabolized was calculated by dividing the amount of carnosine excreted during the 24 hr following the load (after subtracting as baseline the amount excreted in the $24 \mathrm{hr}$ prior to the load) by the amount administered to each subject.

Table 3. Serum carnosinase activity

\begin{tabular}{lcc}
\hline \multicolumn{1}{c}{ Subject } & $\mu$ moles histidine/ml/hr & $\begin{array}{c}\text { Mean control } \\
(\%)\end{array}$ \\
\hline Patient & 0.28 & 14 \\
Father & 1.36 & 68 \\
Mother & 1.30 & 65 \\
Sib 1 & 1.10 & 55 \\
Sib 2 & 1.86 & 93 \\
Controls & $2.00 \pm 0.58$ (mean \pm S.D.) & \\
$\quad$ (7 adults) & $1.10-2.85$ (range) & \\
\hline
\end{tabular}

Table 4. Hepatic enzyme activities

\begin{tabular}{|c|c|c|}
\hline & Patient & Controls \\
\hline $\begin{array}{l}\text { Carnosinase } \\
\text { (nmoles/mg/hr) }\end{array}$ & 87 & 197,212 \\
\hline OTC ( $\mu$ moles $/ \mathrm{g} / \mathrm{hr}$ ) & 6296 & $5185 \pm 706^{1}(7)$ \\
\hline $\begin{array}{l}\text { MTHF transferase } \\
\text { (nmoles/mg/hr) }\end{array}$ & 2.10 & $2.19 \pm 0.97(14)$ \\
\hline $\begin{array}{l}\text { Cystathionine synthase } \\
\text { (nmoles/mg/hr) }\end{array}$ & 158 & $207 \pm 19.3(6)$ \\
\hline
\end{tabular}

Table 5. Summary of data on patients with carnosinuria

\begin{tabular}{|c|c|c|c|c|c|c|}
\hline & $\begin{array}{l}\text { Clinically } \\
\text { affected }\end{array}$ & Carnosinemia & 1- $\mathrm{CH}_{3}$-Histidine & $\begin{array}{l}\text { Serum carnosinase } \\
(\mu \mathrm{moles} / \mathrm{ml} / \mathrm{hr})\end{array}$ & $\begin{array}{c}\text { Hepatic carno- } \\
\text { sinase ( } \% \text { control) }\end{array}$ & References \\
\hline 1. & + & + & 0 & $<0.05$ & & 5,6 \\
\hline 2. & + & 0 & 0 & $<0.04$ & & 5,6 \\
\hline 3. & + & 0 & + & $0.03-0.07$ & & 9 \\
\hline $4 a$. & + & + & + & $<0.03$ & 17 (autopsy) & 3 \\
\hline b. & + & + & + & $<0.03$ & & \\
\hline c. & - & ; & + & Low & & \\
\hline 5. & - & + & $?$ & Normal for age & & 2 \\
\hline 6. & + & 0 & + & $0.28(14 \%)$ & 46 (biopsy) & $\overline{1}$ \\
\hline
\end{tabular}

${ }^{1}$ Present case.

\section{MATERIALS AND METHODS}

Appropriate informed consent was obtained for all studies involving human subjects.

\section{ENZYME ASSAY}

Preparation of Specimens. Heparinized blood (5 to $10 \mathrm{ml}$ ) was centrifuged at $2500 \mathrm{rpm}$, and the supernatant plasma was used for enzymatic analysis or stored at $-70^{\circ} \mathrm{C}$. Liver and nerve specimens were taken during open biopsy for pathologic examination. The tissues were stored frozen in liquid nitrogen until the time of assay. They were then homogenized in 5 volumes of $0.03 \mathrm{M}$ potassium phosphate buffer, $\mathrm{pH} \mathrm{6.9,} \mathrm{and} \mathrm{centrifuged}$ at $18,000 \mathrm{rpm}$ for $30 \mathrm{~min}$; the supernatant fluid was used for assay.

Assay for carnosinase activity was performed according to the method of Perry et al. (5). This method consists of incubating plasma or tissue samples with L-carnosine and measuring the histidine that forms in the reaction using an amino acid analyzer. The incubation time, however, was reduced from 16 to $4 \mathrm{hr}$ because we found that the enzymatic activity was not linear for $16 \mathrm{hr}$. Histidine, the product of the carnosinase reaction, was measured on a 0.9- $\times 10-\mathrm{cm}$ column of Beckman PA-35 resin which was eluted with $0.39 \mathrm{M}$ sodium citrate buffer, $\mathrm{pH} 4.25$, at $55^{\circ} \mathrm{C}$. Histidine was eluted at $70 \mathrm{ml}$ of 'utfer (run at $50 \mathrm{ml} / \mathrm{hr}$ ).

\section{AMINO ACID ANALYSIS}

Carnosine and histidine were measured in plasma, urine, and tissues by conventional basic amino acid analysis using a Beckman $120 \mathrm{C}$ amino acid analyzer (0.9- x 23-cm columns containing Beckman PA-35 basic resin). Samples were prepared as follows. Plasma was separated from heparinized blood by centrifugation. Proteins were removed by precipitation with 5 volumes of $3 \%$ sulfosalicylic acid followed by centrifugation at $10,000 \mathrm{rpm}$ for $20 \mathrm{~min}$. Urine samples were acidified with $1.0 \mathrm{~N}$ hydrochloric acid. Tissues were homogenized in 5 volumes of $10 \%$ trichloroacetic acid and centrifuged as above.

Peaks were integrated and compared with chromatograms of authentic amino acids. Final concentrations were calculated using an on-line computer system (Infotronics CRS-1000).

\section{RESULTS}

Urinary amino acid analysis of a sample from the patient, $S$. T., revealed persistent carnosinuria, even on a meat-free diet, as compared with an aged-matched control (Table 1). The histidine level in the patient's urine was low, but 1-methyl-histidine was measurable in each sample and increased greatly on a high 
anserine (i.e., chicken breast) diet. Amino acid concentrations were normal both in plasma and cerebrospinal fluid.

After ingestion of a carnosine load of $100 \mathrm{mg} / \mathrm{kg}$ of body weight, the patient had a greatly increased excretion of carnosine as compared with an age-matched control (Table 2). Histidine, however, increased only very slightly in the patient, whereas the urinary histidine in the control subject increased 4-fold during the first $4 \mathrm{hr}$. During the first hr after the load, the patient did have a small amount of carnosine $(11.5 \mu$ moles $\%)$ in his plasma; this was not observed again. During the $24 \mathrm{hr}$ after the load, the patient excreted about $28 \%$ of the administered load as carnosine, as compared with $1.3 \%$ excreted by the control subject (Table 2 ).

Plasma carnosinase activity in the patient was $0.28 \mu$ moles per $\mathrm{ml}$ plasma per hr which represents $14 \%$ of the mean control value (Table 3 ). The parents and one sib had reduced plasma enzyme activity, and a second sib had normal carnosinase activity.

We have been able to demonstrate carnosinase activity for the first time in human peripheral nerve, and we have shown that extracts of a sural nerve biopsy from the patient had activity that was $46 \%$ of a control biopsy (patient $=23$ nmoles per $\mathrm{mg}$ protein per hr; control $=50$ ). Histopathologic examination of the patient's nerve showed axonal degeneration (10).

Enzymatic studies in extracts of a liver biopsy from the patient demonstrated a specific reduction in carnosinase activity (Table 4). Three other hepatic enzymes, ornithine transcarbamylase, $N^{5}$ methyltetrahydrofolate homocysteine methyltransferase, and cystathionine $\beta$-synthase, were all within the normal range of activity. Carnosinase activity, however, was reduced to about $43 \%$ of control biopsy values. The activity of ornithine transcarbamylase is of special interest in this patient because of an earlier report demonstrating plasma carnosinase deficiency in patients with urea cycle defects (1). We have examined urine from several patients with various urea cycle defects and have not detected carnosine in any of them (7).

Histidine concentrations in the patient's liver and nerve were normal, and neither $\beta$-alanine, carnosine, nor homocarnosine was detectable.

\section{DISCUSSION}

The data that have accumulated during the last ten years on patients with carnosinuria present both a clinically and biochemically heterogeneous picture (Table 5; Refs. 3, 5, 6, 8, 9). Neither the presence of carnosine in plasma/serum nor the absence of 1methyl-histidine in urine is a consistent finding. Plasma carnosinase activity, although consistently low in these patients, appears to bear no constant relation to the other 2 findings. Some patients with very low plasma activity are also carnosinemic and do not metabolize anserine to 1-methyl-histidine $(5,6)$, others with activ- ity just as low show no plasma carnosine and do produce 1methyl-histidine (9), and still others show both carnosinemia and 1 -methyl-histidine $(3,8)$. We believe that our patient may represent a variant form of carnosinase deficiency. Biochemically, he appears minimally affected. His residual plasma enzymatic activity is unusually high compared with other patients. He is capable of hydrolyzing anserine to l-methyl-histidine when challenged with a high anserine diet. He has significant tissue enzyme activity and does not show any accumulation of carnosine in his tissues.

So viewed, we would have expected such a patient to have a relatively mild form of the disorder. He is, however, severely affected clinically. This finding, in addition to the two apparently unaffected carnosinuric children that have been reported $(2,3)$, points out an important question yet to be answered about this disorder. Is carnosinuria due to plasma carnosinase deficiency merely associated with the striking neurological findings, rather than causally related?

\section{REFERENCES AND NOTES}

1. Burgess, E. A., Oberholzer, V. G., Palmer, T., and Levin, B.: Plasma carnosinase deficiency in patients with urea cycle defects. Clin. Chim. Acta, 61: 215 (1975).

2. Gordon, E. F., Jr., Coulombe, J. T., Sepe, S. J., and Levy, H. L.: A variant of carnosinemia with normal serum camosinase activity in an infant. Pediatr. Res. (Abstract), 11: 456 (1977).

3. Murphey, W. H., Lindmark, D. G., Patchen, L. I., Housler, M. E., Harrod, E. K., and Mosovich, L.: Serum carnosinase deficiency concomitant with mental retardation. Pediatr. Res., 7: 601 (1973).

4. Murphey, W. H., Patchen, L. I., and Lindmark, D. G.: Carnosinase. A fluorometric assay and demonstration of two electrophoretic forms in human tissue extracts. Clin. Chim. Acta, 42: 309 (1972).

5. Perry, T. L., Hansen, S., and Love, D. L.: Serum-camosinase deficiency in carnosinaemia. Lancet, I: 1229 (1968).

6. Perry, T. L., Hansen, S., Tischler, B., Bunting, R., and Berry, K.: Carnosinemia: a new metabolic disorder associated with neurologic disease and mental defect. N. Engl. J. Med., 277: 1219 (1967).

7. Rassin, D. K., and Fleisher, L. D.: (unpublished observations).

8. Terplan, K. L., and Cares, H. L.: Histopathology of the nervous system in carnosinase enzyme deficiency with mental retardation. Neurology, 22: 644 (1972).

9. van Heeswijk, P. J., Trijbels, J. M. F., Schretlen, E. D. A. M., van Munster, P. J. J., and Monnens, L. A. H.: A patient with a deficiency of serum carnosinase activity. Acta Paediatr. Scand., 58: 584 (1969).

10. Wisniewski, K., Fleisher, L., Rassin, D., and Lassman, H.: Peripheral neuropathy with camosinase deficiency in a child with neurological disease. Neuropadiatrie, submitted for publication (1980).

11. The authors would like to thank Dr. Gerald E. Gaull for many hours of useful discussion and, as always, for his encouragement and support.

12. Requests for reprints should be addressed to: Lynn D. Fleisher, Ph.D., Department of Human Development and Nutrition, New York State Institute for Basic Research in Mental Retardation, 1050 Forest Hill Road, Staten Island, New York 10314 (USA).

13. This research was supported by the New York State Office of Mental Retardation and Developmental Disabilities.

14. Received for publication January 24, 1979.

15. Accepted for publication June 14, 1979. 